\title{
Detection of Chrysops divaricatus (Diptera: Tabanidae) in Flat Pastures of the Central Yakutia Russian Federation
}

\author{
Alexander Dmitrievich Reshetnikov and Anastasia Ivanovna Barashkova \\ Laboratory of Arachnoentomology Yakut Scientific Research Institute of Agriculture, 23/1, Bestuzheva-Marlinskogo Str., Yakutsk, \\ The Republic of Sakha (Yakutia), 677001, Russia
}

\begin{abstract}
In Central Yakutia of the Russian Federation 21 species and subspecies of horseflies of two genera are revealed: Chrysops (6 species) and Hybomitra (15 species and 1 subspecies). There are two marked species (dark forms): H. bimaculata var.bisignata and $H$. montana var. flaviceps. The most numerous species being the main center of population on pastures are 6: Hybomitra montana montana, $H$. lundbecki lundbecki, H. ciureai, H. arpadi, H. nitidifrons nitidifrons, $H$. nigricornis (in the amount of $81.46 \%$ fees). On the plain pastures Chrysops divaricatus is specified for the first time.
\end{abstract}

Key words: Chrysops divaricatus, horseflies, pastures of horses.

\section{Introduction}

Horseflies forming the Tabanidae family, including in the suborder of Diptera (Brachycera, Orthorrapha) are the largest representatives of the bloodsucking dipterous insects. It also includes mosquitoes, gnats, midges. Horseflies are found in almost all countries, including in the Russian Federation [1, 2].

According to professor N. G. Olsufyev (1977) in the territorv of Russia 114 species and 20 subspecies often orders of 500 species known for Palaearctic area meet [3]. The fauna of horseflies of various zones of Yakutia was studied by many researchers [4-8]. The basic researches are conducted by T. T. Vasyukova [9] in the Central and Southern parts of the republic. The specific composition of horseflies was submitted by 33 species and 4 subspecies which concern about six genus among which Hybomitra montana (50.09\%), $H$. lundbecki (13.95\%) and H. ciureai (13.84\%) are mass, and numerous- $-H$. nitidifrons (7.3\%), $H$. distinguenda (3.88\%), H. lurida (2.57\%) and Chrysops nigripes

Corresponding author: Alexander Dmitrievich Reshetnikov, Ph.D., professor, research field: entomology.
(2.36\%) making in the sum of $94.42 \%$. However in Yakutia more than 30 years the studying of the fauna of horseflies was not almost engaged. The purpose of our researches is studying of specific structure of horseflies of the Central Yakutia of the Russian Federation.

\section{Materials and Methods}

Research area: Yakutia is located in the north-east of Asia between $76^{\circ} 3^{\prime}-55^{\circ} 29^{\prime}$ north latitude and $105^{\circ} 3^{\prime}-162^{\circ} 51^{\prime}$ east longitude (Fig. 1). The area of Yakutia (3,103,2 thousand sq. $\mathrm{km})$ occupies $18 \%$ or almost one-fifth of the Russian Federation territory. The area of research is in the territory of the Central Yakutia as a part of Russia. The western point is on border with Krasnoyarsk Krai $\left(109^{\circ} 30^{\prime} \mathrm{EL}\right)$, east—on border with the Aldan River $\left(135^{\circ} 30^{\prime}\right.$ EL), southern-on $60{ }^{\circ} \mathrm{C}$ highway, northern-on $64{ }^{\circ} \mathrm{C}$ north latitude. This is the area of the northern hemisphere cold pole which is characterized by wide temperature fluctuations. The January long-term mean air temperature in Oymyakon and Verkhoyansk is minus $49-50{ }^{\circ} \mathrm{C}$. In Oymyakon the temperature reaches 


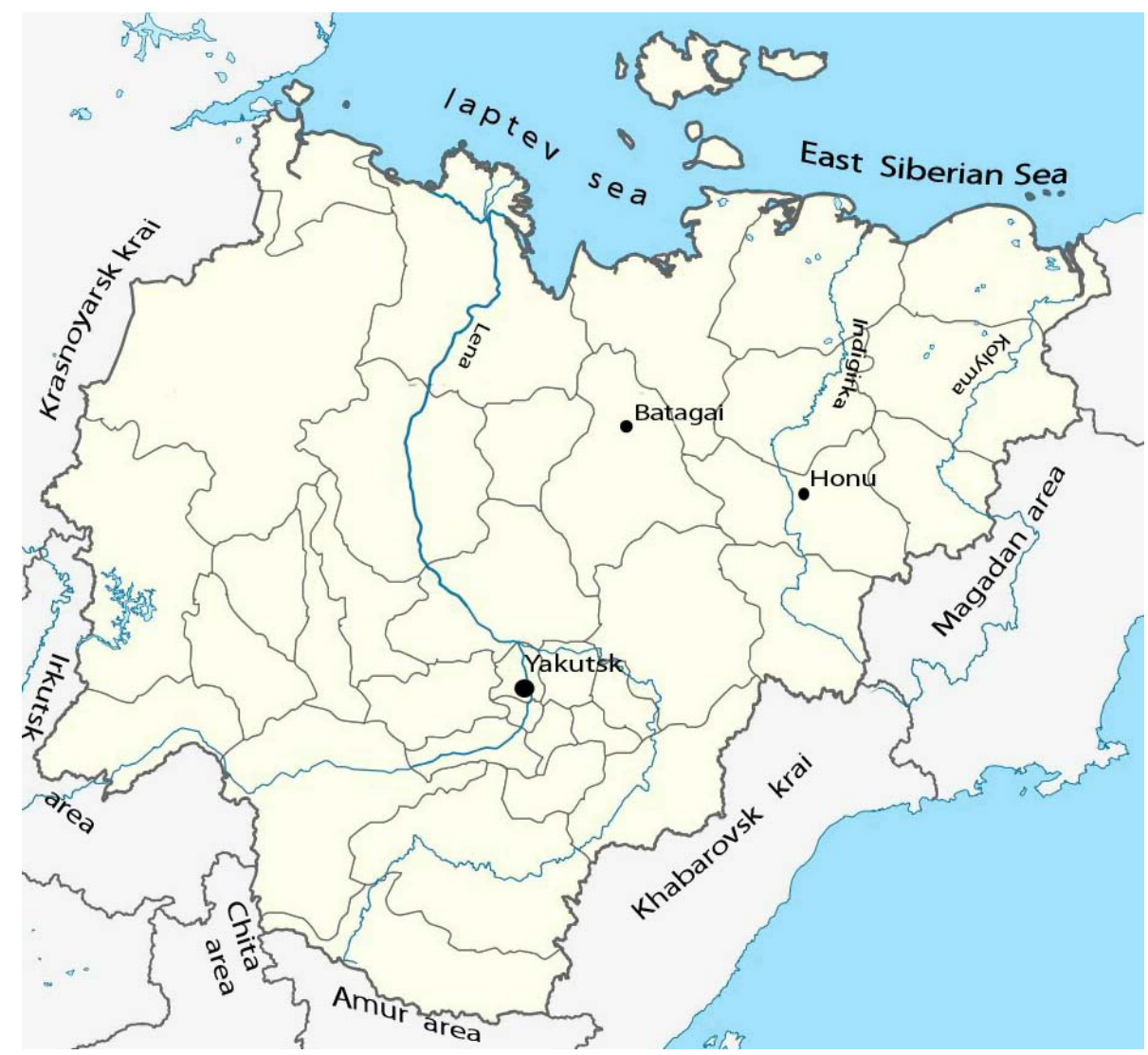

Fig. 1 The Republic of Yakutia (Sakha) of the Russian Federation.

minus $71^{\circ} \mathrm{C}$, in Verkhoyansk minus $68^{\circ} \mathrm{C}$ and in the central regions the temperature is minus $66{ }^{\circ} \mathrm{C}$. The summer is short, but relatively hot (in most of republic the maximum temperature is plus $36-38{ }^{\circ} \mathrm{C}$ ), with a long sunshine duration (a continuous polar day). In 2003 in Yakutia the number of horses was 168.2 thousand, reindeers-174.8 thousand and cattle-234.4 thousand animals.

The experimental part of work was carried out on the pastures of horses, cattle and deer in the Central Yakutia, cameral processing of collected material was carried out in Yakut Research Institute of Agriculture, the Russian Research Institute of veterinary entomology and arachnology. Stationary researches on studying of specific structures and ecology of horseflies were carried out in 2000-2015 in the Central Yakutia. Faunistic collecting and the accounting of number of the attacking imago of horseflies was carried out by carrying out accounts on animals, their catching by means of an entomological net with removable sacks and traps in hours of the greatest activity of bloodsucking dipterous insects during all summer seasons two times a decade and twice during the season within a day every two hours. One account of horseflies is 10 waves ("eight") in 10 redoes during seasonal dynamics of population and in 5 redoes during daily activity.

For systematic collecting and the accounting of quantity of horseflies on pastures a chucheloobrazny trap of K. V. Skufyin [10] and [11] yulovidny trap developed by S. D. Pavlov and R. P. Pavlova were used. Skufyin's trap is a black canopy of sateen $165 \mathrm{~cm}$ long and $60 \mathrm{~cm}$ high, strained on the wooden frame $130 \mathrm{~cm}$ high. On the top of a roundish hole of canopy of a trap the cage catcher is set. Horseflies are attracted by black canopy and, they get under canopy from below to the darkened space. Owing to a positive fototaksis horseflies fly on light arriving through an opening in 
canopy and get to a cage.

The Yulovidny trap consists of the following main elements: (1) the yulovidny attracting device executed from two metal cones (funnels) connected by the bases; (2) transparent polyethylene cone canopy with a neck in narrow top part; (3) versheobrazny cage catcher. All this is mounted on the гаек withheld in vertical position by the extensions fixed to the ground. The principle of trap is: the horseflies attracted by the black device get under transpired canopy. Owing to negative geotropism they seek to fly up to the open space, and the canopy sends them to a cage catcher.

For killing of the insects caught by a trap the cage catcher was placed in a plastic bag where the cotton wool moistened with ether was put. If there were few insects, they were caught from a cage and placed in the tubes. The insects caught by a net together with a removable sack were placed in bank wood stain at the bottom of which there were slices of a rubber tube impregnated with ether. The destroyed insects in 30-40 minutes were displayed ranks on wadded mats supplied with a label. Separate copies were pinned on entomological pins No. 1-3 placed in entomological boxes. The pinned insects were supplied with a label with the indication of the name of the district or settlement, date and a method of catching, a surname of the collector.

For identification of horseflies we used the attributives tables of monographs of N. G. Olsufyev (1977) and N. A. Violovich (1968).

The flight of insects registered 3 times a day (at 7, 13 and 19 o'clock local time) meteorological data. The temperature and humidity of air were measured by the aspiration psychrometer, wind speed-the ASO-3 anemometer, atmospheric pressure-the aneroid barometer, illumination — the Yu-116 light meter, overcast-visuallyon a 10-mark scale, an amount of precipitation a rain gage. Besides, meteodata of weather station Meteo link IQ557 is used.

In the study of fauna and ecology of horseflies, mosquitoes, midges it is made more than 80 accounts by traps and about 100 accounts on animals are carried out, 4,409 females of gadflies are collected and defined. Correctness of definition of specific structure of a collection of blood-sucking dipterous insects is confirmed by professor R. P. Pavlova (Tyumen).

\section{Results and Discussion}

The climate of the Central Yakutia is very favorable for dwelling of gadflies. Flight of gadflies is observed since the end of the first decade of June to the middle of the first decade of August and averages 58 days. The period of mass summer when attacking one horse to $83-150$ gadflies for the 15-minute account, proceeds about a month from third decade of June to the second decade of July. Daily activity of gadflies keeps within a one-topmost curve and proceeds with 8 to 20 with a maximum at 12-16 o'clock. The lower temperature threshold is equal $+16{ }^{\circ} \mathrm{C}$, and optimum temperature +25 to $+31^{\circ} \mathrm{C}$.

On pastures of horses in the Central Yakutia as a result of the conducted researches we established existence of 21 species and 1 subspecies of the gadflies belonging to 2 genus: Chrysops (6 species) and Hybomitra (15 species and 1 subspecies) (Table 1). Besides, varyeteta (dark forms) of two types are found: Hybomitra bimaculata var. bisignata and $H$. montana var. flaviceps. Apparently from the table, in the Central Yakutia the sort Hybomitra differs in the greatest specific variety.

Dominating species were Hybomitra montana montana (45.29\%), H. lundbecki lundbecki (24.97\%) and $H$. ciureai (11.20\%), sub-dominating- $H$. arpadi (5.85\%), $H$. nitidifrons (4.03\%) and $H$. nigricornis (2.97\%) in the sum these types are made $94.31 \%$ of collecting. Two species were small $H$. lurida (1.88\%), $H$. lundbecki sibiriensis (1.13\%), which made $3.1 \%$ in collecting. Other 13 species and 1 subspecies belong to group rare and make in collecting $2.59 \%$.

In comparison with earlier known in our collecting from flat pastures there are no Chrysops makerovi Pl., Chr. caecutiens caecutiens L., Chr. suavis Lw., Hybomitra 
Table 1 Specific structure of horseflies on pastures of horses in the Central Yakutia.

\begin{tabular}{|c|c|c|c|c|}
\hline \multirow{2}{*}{$\begin{array}{l}\text { \#Sequence } \\
\text { numbers }\end{array}$} & \multirow{2}{*}{ Species } & \multicolumn{2}{|c|}{ Number of horseflies } & \multirow{2}{*}{-Degree of abundance } \\
\hline & & Number of individuals & Domination Index \% & \\
\hline \multicolumn{5}{|c|}{$\begin{array}{l}\text { Subfamily Chrysopsinae } \\
\text { Tribus Chrysopsini } \\
\text { Genus Chrysops Mg. } \\
\text { 1. Subgenus Chrysops s. str. }\end{array}$} \\
\hline 1. & Chr. (s. str.) nigripes Ztt. & 12 & 0.27 & + \\
\hline 2. & Chr. (s. str.) divaricatus Lw. & 5 & 0.11 & + \\
\hline 3. & Chr. (s. str.) validus Lw. & 12 & 0.27 & + \\
\hline 4. & Chr. (s. str.) relictus Mg. & 3 & 0.06 & + \\
\hline 5. & Chr. (s. str.) ricardoae jakutensis Ols. & 9 & 0.20 & + \\
\hline \multicolumn{5}{|c|}{ 2. Subgenus Heterochrysops Krob. } \\
\hline 6. & Chr. (H.) vanderwulpi Krob. & 1 & 0.03 & + \\
\hline \multicolumn{5}{|c|}{$\begin{array}{l}\text { Subfamily Tabaninae } \\
\text { Tribus Tabanini } \\
\text { Genus Hybomitra End. } \\
\text { 3. Subgenus Hybomitra s. str. }\end{array}$} \\
\hline 1. & H. (s. str.) sexfasciata Hine. & 21 & 0.47 & + \\
\hline 2. & H. (s. str.) olsoi Takah. & 9 & 0.20 & + \\
\hline 3. & H. (s. str.) arpadi Szil. & 258 & 5.85 & +++ \\
\hline 4. & H. (s. str.) pavlovskii Ols. & 4 & 0.09 & + \\
\hline 5. & H. (s. str.) tarandina L. & 5 & 0.11 & + \\
\hline 6. & H. (s. str.) aequetincta Beck. & 3 & 0.06 & + \\
\hline 7. & H. (s. str.) lurida Flln. & 83 & 1.88 & ++ \\
\hline 8. & H. (s. str.) nitidifrons nitidifrons Szil. & 178 & 4.03 & +++ \\
\hline 9. & H. (s. str.) distinguenda contigua Ols. & 21 & 0.47 & + \\
\hline 10. & H. (s. str.) ciureai Seg. & 494 & 11.21 & ++++ \\
\hline 11. & H. (s. str.) muehlfeldi Br. & 3 & 0.06 & + \\
\hline 12. & H. (s. str.) bimaculata var.bisignata Jaenn. & 1 & 0.02 & + \\
\hline 13. & H. (s. str.) nigricornis Ztt. & 131 & 2.97 & +++ \\
\hline 14. & H. (s. str.) lundbecki lundbecki Lyn. & 1,101 & 24.97 & ++++ \\
\hline $14 \mathrm{a}$ & H. (s. str.) lundbecki sibiriensis Ols. & 50 & 1.13 & ++ \\
\hline 15. & H. (s. str.) montana montana Mg. & 1997 & 45.29 & ++++ \\
\hline $15 \mathrm{a}$ & H. (s. str.) montana var. flaviceps Zett. & 8 & 0.18 & + \\
\hline & In total: 21 species and 1 subspecies & 4,409 & 100.0 & \\
\hline
\end{tabular}

Note: ++++ - dominating species, +++ - subdominating, ++ - small, + -rare.

lapponica Wahlb., H. astuta O. S., H. astur Erichs., H. distinguenda f. obscura, H. lundbecki f. obscura, Tabanus geminus Szil., Haematopota pluvialis L., but in addition to the list there are Chrysops divaricatus, Hybomitra aequetincta.

\section{Conclusions}

In Central Yakutia of the Russian Federation 21 species and 1 subspecies of horseflies of two genera are revealed, related to two genera: Chrysops (6 species) and Hybomitra (15 species and I subspecies).
There are two marked species (dark forms): $H$. bimaculata var. bisignata and $H$. montana var. flaviceps. The most numerous species being the main center of population on pastures are 6: Hybomitra montana montana, H. lundbecki lundbecki, H. ciureai, $H$. arpadi, $H$. nitidifrons nitidifrons, $H$. nigricornis, in the sum they are $81.46 \%$. For flat pastures Chrysops divaricatus specified for the first time.

\section{References}

[1] Müller, G. C., Revay, E. E., Hogsette, J. A., Zeegers, T., 
Kline, D., Kravchenko, V. D., and Schlein, Y. 2012. “An Annotated Checklist of the Horse Flies (Diptera: Tabanidae) of the Sinai Peninsula Egypt with Remarks on Ecology and Zoogeography: Original Research Article.” Acta Tropica. 122 (2): 205-11.

[2] Al Dhafer, H. M., Dawah, H. A., and Abdullah, M. A. 2009. "Tabanidae (Diptera) of Saudi Arabia. Original Research Article.” Saudi Journal of Biological Sciences 16 (2): 77-83.

[3] Olsufyev, N. G. 1977. "Fauna of the USSR: Fam. Tabanidae.” Insects Diptera 7 (2): 436.

[4] Violovich, N. A. 1968. Tabanidae Siberia: 283.

[5] Yakuba, V. N. 1963. "Blood-Sucking Two-Winged Insects of Yakutia and Their Epidemiological Significance.” Problems of Parasitology: Coll. AN USSR: 431-3.

[6] Barashkova, A. I. 2003. "Bioecological Principles of Protecting Horses from Gadflies (Diptera, Tabanidae) in
Central Yakutia.” PhD thesis.

[7] Barashkova, A. I., Pavlova, R. P., and Reshetnikov, A. D. 2005. "Fauna of Gadflies of Central Yakutia." Proceedings of the All-Russian Institute of Helminthology named after KI Scriabin 41: 65-72.

[8] Reshetnikov, A. D., and Vasilevich, F. I. 2003. "Diptera: Gasterophilidae, Culicidae, Tabanidae, Ceratopogonidae, Simuliidae in Conditions of the Sakha Republic (Yakutia) of Russian Federation (Fauna, Ecology, phenology, Control of Number).” Monography, 220.

[9] Vasyukova, T. T. 1973. "Diptera, Tabanidae Central and South Yakutia." PhD thesis.

[10] Skufyin, K. V. 1973. "Methods of Collecting and Studying Gadflies.”

[11] Pavlov, S. D., and Pavlova, R. P. 1986. "Methodical Recommendations on the Use of Traps for Collecting, Counting and Eliminating Gadflies on Pastures.” 